DOI: 10.1515/pof-2017-0026

VOLUME 9, ISSUE 3, 2017

ISSN: $2036-5438$

\title{
In Memoriam: Prof. Alessandro Pizzorusso \\ by
}

Paolo Carrozza and Giuseppe Martinico

Perspectives on Federalism, Vol. 9, issue 3, 2017 
In the introduction we discussed how this special issue was the product of a conference organized in Pisa on 24 May 2017. The conference was conceived as part of the Sant'Anna Legal Studies Project (STALS), a project on which we have the honour of coordinating with Giacomo Delledonne and Filippo Fontanelli. STALS was launched in 2008, with the creation of an online research paper archive; since then it has grown significantly, we have organized almost ninety international events on different topics, covering a broad spectrum of interests. Over the last few years the Scuola has invested significantly to achieve a constant growth in internationalising our activities; a process that has enjoyed a significant acceleration under the Presidency of Prof. Yves Mény.

Along with Richard, Antonia and Cristina, the other convenors of this event, we thought that it might be a good idea to devote an international symposium to "The Constitution of Canada: History, Evolution, Influence and Reform", by exploiting, so to speak, the chance offered by the 150th Anniversary of the Canadian Confederation.

We decided to dedicate this event to the memory of Prof. Alessandro Pizzorusso (Bagni di Lucca 11 November 1931- Pisa 14 December 2015). He was an outstanding scholar, a giant in our discipline.

Moreover and, perhaps more importantly, he was also a very humble person who always escaped celebrations, a role model for the younger generations.

Alessandro Pizzorusso started work as a judge, and then became Professor of Constitutional and Comparative Law at the Universities of Pisa and Florence. He was also Emeritus Professor at the University of Pisa. He authored more than 1,000 publications in Italian, French, Spanish and English. His works were translated into many different languages. He covered a very wide spectrum of topics related to domestic, comparative and European constitutional law. He was also part of the Expert Group on Fundamental Rights chaired by Spiros Simitis, as such contributing to the progressive constitutionalisation of the EU, as that group put forward some very important recommendations for the inclusion of a Bill of Rights in the Treaties. He was also member of the Italian Superior Council of the Judiciary, of the prestigious "Accademia Nazionale dei Lincei", and of the International Academy of Comparative Law. 
Among his works in English comes to mind in particular his article "Italian and American Models of the Judiciary and of Judicial Review of Legislation: A Comparison of Recent Tendencies", published in the American Journal of Comparative Law in 1990. He was also Editor of the Italian Studies in Law, with the specific goal of circulating the best outputs of Italian scholarship.

We benefited from his superb intellectual and human qualities, immense legal knowledge and generosity. There is an anecdote we want to share with our readers and which is related to the genesis of STALS. As written, we wanted to launch the website and the paper archive at that time.

STALS has been made possible thanks to the support of Emanuele Rossi and other colleagues at Scuola Sant'Anna. This project was modelled on the Italian Studies in Law, a sort of a yearbook series edited between 1992 and 1994 by Alessandro Pizzorusso and published by Martinus Nijhoff.

In our view STALS had to be (and to a certain extent is) a sort of follow up to the Italian Studies in Law project, but with a huge difference, as STALS relies on an electronic platform.

It was no coincidence, therefore, that we asked Alessandro Pizzorusso to launch the STALS website with a paper of his; we understood that his contribution was a sign of continuity with the experience of Italian Studies in Law.

We immediately contacted Alessandro Pizzorusso and he decided to give us a paper entitled "Common constitutional traditions as Constitutional Law of Europe?".

In the paper you can find the essence of his way of understanding European Law; a sort of huge space that can be filled, fed and enriched by comparative law. This is also the idea behind one of his books, Il patrimonio costituzionale europeo ("the European constitutional heritage).

Indeed, European constitutional law was one of the many fields in which Alessandro Pizzorusso wrote fundamental pieces, teaching us the importance of comparison in European studies.

His interest in European law may have been due to his connection with Mauro Cappelletti (he moved to Florence to replace Cappelletti as, among other things, Director of the Institute of Comparative law of the University of Florence); perhaps in this experiment of legal and cultural coexistence he found a natural follow up to his works on 
linguistic and cultural diversity. He wrote extensively on linguistic minorities and in these works it is also possible to find some references to Canada. As an example, in a piece published in the Boletín Mexicano de derecho comparado in 2000, he briefly dealt with Ford v Quebec (AG), [1988] 2 S.C.R. 712 a very well know decision of the Canadian Supreme Court in which legislation restricting the use of commercial signs written in languages other than French was struck down. The Canadian Supreme Court acknowledged the violation of the freedom of expression as enshrined in the Canadian Charter of Rights and Freedoms. Prof. Pizzorusso had many contacts in Canada as well, José Woehrling and Prof. Andrée Lajoie, among others. He always shared his network with us and this testifies again to his generosity.

Always thanks to these contacts we had the privilege of meeting another giant of comparative law, another gentleman, Prof. Patrick Glenn who passed away some months earlier than Alessandro Pizzorusso.

We mention this because Patrick Glenn wrote our second STALS research paper, another jewel entitled "Doin' the Transsystemic: Legal Systems and Legal Traditions".

However, if we only recall Alessandro Pizzorusso's scientific guidance then we would not get the entire picture, as his greatest legacy to the academic community was his incredible generosity and immense respect for students, colleagues and members of the administrative staff.

Our sadness really goes beyond the power of speech, we cannot contain what we feel; we miss him greatly, and the unfinished conversations we had started with him. 